Masthead Logo

NYLS Journal of International and

Comparative Law

Volume 3

Issue 1 Volume 3, Number 1, 1981

Article 3

1981

\title{
Sharing of Ocean Resources - Unresolved Issues in the Law of the Sea
}

Shigeru Oda

Follow this and additional works at: https:// digitalcommons.nyls.edu/

journal_of_international_and_comparative_law

Part of the Law of the Sea Commons, National Security Law Commons, and the Natural Resources Law Commons

\section{Recommended Citation}

Oda, Shigeru (1981) "Sharing of Ocean Resources - Unresolved Issues in the Law of the Sea," NYLS Journal of International and Comparative Law: Vol. 3 : Iss. 1 , Article 3.

Available at: https://digitalcommons.nyls.edu/journal_of_international_and_comparative_law/vol3/iss1/3

This Article is brought to you for free and open access by DigitalCommons@NYLS. It has been accepted for inclusion in NYLS Journal of International and Comparative Law by an authorized editor of DigitalCommons@NYLS. 


\title{
JOURNAL OF INTERNATIONAL AND COMPARATIVE LAW
}

\section{SHARING OF OCEAN RESOURCES - UNRESOLVED ISSUES IN THE LAW OF THE SEA*}

\author{
SHIGERU ODA**
}

Mr. Dean and distinguished members of the Faculty of the New York Law School: it is my great honour to have been invited by your law school to speak as the Walter M. Jeffords lecturer today. That I have sufficient merit to be given this honour today is due in no small measure to the legal education that I received in this country. If I were allowed to mention only one name, it must be that of Professor Myers S. McDougal of your Faculty. If I had not met Professor McDougal, and pursued my studies under his guidance in New Haven between 1950 and 1953, my life would have moved in a different direction and I would not be where I am today.

Mr. Dean and distinguished faculty members, ladies and gentlemen: It has been thirty years since I studied international law in this country. In these thirty years, a great deal of my work on international law has been devoted to the Law of the Sea, and my interest has centered on the problem of the sharing of marine resources. Professor McDougal will probably agree that he and I were among the few who pre-

*This is the text of the lecture that the author delivered at New York Law School on September 1, 1981 as its Seventh Distinguished Walter M. Jeffords Lecturer. On that date, the text of the Third United Nations Conference on the Law of the Sea: Draft Convention on the Law of the Sea, U.N. Doc. A/Conf.62/L.78 (1981) was not yet available, and the achievements of the Tenth Session of the Third United Nations Conference on the Law of the Sea were unknown to the author.

The following are some of the author's works that are relevant to this lecture: International Control Of Sea Resources (1963); The Law Of The Sea In Our Tmas - I: New Developments 1966-1975 (1977); International Law Op The Resources Op The Sen (1979); The Ocean: Law and Politics, 25 Neth. Int'l L. Rev. 149 (1978).

* Judge of the International Court of Justice. LL.B. University of Tokyo, 1947; LL.M. Yale University, 1952; J.S.D. Yale University, 1953; LL.D. Tohoku University, 1962. 
dicted, as far back as the early 1950's, the future conflicts and confusions among national interests involved in the sharing of ocean resources. I should like to take this opportunity to discuss the question of how ocean resources has been dealt with under international law. My remarks will thus constitute for me, in part, a reminiscence of my work of the past thirty years. I think that I shall also be able to pinpoint some of the problems that face us both today, and in the future, as regards the question of the ocean.

\section{II}

As a preliminary observation, I must recall how the ocean became the object of the interest of the people of the world and has been made subject to the regulations of international law.

First, for centuries past, the ocean has been used universally as a common concourse for maritime traffic. Such use of the ocean, being in the interest of all nations, with no one nation assailing the interest of others by claiming its exclusive use, has led to the creation of advanced regulations for the promotion and safe control of traffic. Subject only to such regulations of a technical nature, the freedom of maritime traffic has continued to remain the most well-established rule of international law to be followed by nations. Since this freedom is in the common interest of all nations, and innocent passage is guaranteed in the narrowly-limited territorial seas around the coasts, the traditional dualism of the high seas and the territorial seas in international law does not have a great impact on such use of the ocean.

The second aspect of the use of the ocean relates to national security. The ocean has been a common battleground for naval vessels of the sovereign nations, and freedom for the maneuver of naval fleets has undoubtedly been secure. In fact, only a handful of the great powers remain consistently alert to this aspect, and the United States in particular was strongly concerned with it in the first and second Conferences on the Law of the Sea in 1958 and 1960, when it tried by every means to keep the territorial seas as narrow as possible in order to ensure that the free maneuver of its naval fleet would not be hindered by the closure of any straits of strategic importance. Both conferences, however, failed to hit upon a uniform limit for the narrower territorial seas. Realizing that the main interest of the developing countries lay in the resource aspect of the ocean, and that, if the pressure of a group of developing countries was kept up, the acceptance of a twelve-mile territorial sea could not be avoided, the United States tried to lure the group into accepting its narrowly-limited territorial seas policy, even offering some substantial interest in the use of ocean resources in the offshore areas for the benefit of the developing countries. Thus, early in 1970, the Nixon Administration announced the belief of the United 
States Government that the time was ripe for the conclusion of a new international treaty fixing the territorial sea at twelve miles, provided that freedom of transit through international straits and carefully defined preferential fishing rights for coastal states were also recognized. ${ }^{1}$ The aim of securing the free maneuver of naval fleets seems to have been achieved after somewhat lengthy negotiations in UNCLOS III, as the concept of transit passage of warships through international straits has now been recognized in Part III of the Draft Convention on the Law of the Sea (Informal Text) prepared last year, some articles of which are specifically devoted to "straits used for international navigation.",

The third aspect of the ocean, which relates to the exploitation of marine resources, seems to be one of the greatest problems still remaining insufficiently discussed in UNCLOS III. Thus, I should like today to take up this question of the Law of the Sea as seen from the resource aspect.

\section{III}

First of all, we must bear in mind the fact that interests in the development of resources in general are bound to bring about frequent conflicts, so long as the world community consists of co-existing sovereign nations. The resources of the land covering nearly one-third of the globe are divided among nations by land frontiers which were drawn for various historical and political reasons. The global land resources have never been evenly allocated among the sovereign nations; some States are in advantageous positions, while others are not. Yet these unevenly distributed land resources of the sovereign nations, which have often been the cause of war in the past, are not today made the object of redistribution. While in past colonial ages land resources in Asia and Africa were often grabbed by colonial powers, the new concept of permanent sovereignty over natural resources, as proclaimed in the United Nations General Assembly resolution of $1962,{ }^{8}$ can now save these resources from exploitation by foreign powers and preserve them for the benefit of each sovereign nation. In the field of international law today, the exclusive control of land resources by each nation

1. Nixon, U.S. Foreign Policy for the 1970's: A New Strategy for Peace - A Report to the Congress (Feb. 18, 1970), 62 Dep'T StaTe Bull. 274 (1970).

2. Third United Nations Conference on the Law of the Sea: Draft Convention on the Law of the Sea (Informal Text), arts. 34-39, 41-42, 44-45, U.N. Doc. A/Conf.62/WP.10/ Rev.3 (1980) [hereinafter cited as Draft Convention (Informal Text)]. The Third United Nations Conference on the Law of the Sea: Draft Convention on the Law of the Sea, U.N. Doc. A/Conf.62/L.78 (1981) [hereinafter cited as Draft Convention] is, in these articles, identical to the Draft Convention (Informal Text).

3. G.A. Res. 1803, 17 U.N. GAOR Supp. 107, U.N. Doc. A/5344/Add. 1 (1962). 
is no longer challenged, and no one doubts that access to the land and to its resources is exclusively reserved to each sovereign nation and retained in its hands.

In contrast, the resources of the ocean, which covers two-thirds of the globe, were long considered as common to all. Few ever doubted that the traditional concept of freedom of the high seas would also apply to the exploitation of ocean resources. The fact was that, with respect to ocean resources, the mutually conflicting and excluding interests of nations had not yet come to light before the Second World War. The ocean was not then considered from the aspect of its resources, except perhaps in some narrowly confined offshore areas; the science and technology of such utilization, as well as the demand for ocean resources, had not yet reached the stage where international regulations for this purpose were necessary. If there were any legal implications relating to the exploitation of ocean resources, the extent of the territorial sea was regarded as the sole issue, since this was deemed to coincide with the outer limit of the exclusive use of the coastal nation's sea resources, while the resources of the vast ocean, being infinite and renewable, could be utilized by any nation without detriment to the interests of others. There was, at least in the period prior to the Second World War, no incentive to prevent free access to ocean resources. Thus the freedom of the seas in this respect, as simply an abstract concept, remained unchallenged, and the concept of free access remained a principle in this field, with no one opposing the idea that those who wanted, and were able, to exploit the marine resources were free to do so.

In the post-war period, the development of international law relating to ocean resources has marked something of a revolution in the whole history of international law. Some parts of the ocean, which had been considered if theoretically and in abstracto as free for all, now stand under the regime of the exclusive control of each coastal State. The concepts of the continental shelf and the exclusive economic zone, which were not known at all under traditional international law, are now being introduced.

Now let me begin with the concept of the continental shelf. It was only after the Second World War that the possibility of profitably working the petroleum resources of the continental shelf became the subject of the attention of some nations. In 1945, the United States claimed the submarine areas off. its coasts, thus excluding access by 
other nations to offshore deposits of petroleum. ${ }^{4}$ Many other coastal States then followed suit, undoubtedly because, in so doing, they had much to gain and nothing to lose. There was almost no resistance from any corner of the world to countries monopolizing offshore seabed petroleum in the name of the continental shelf. In those days, foreign interests saw no loss to themselves involved in a country's working the petroleum resources of its own offshore areas, since the exploitation of seabed petroleum in the offshore areas of other countries was hardly considered possible without the cooperation of those other coastal nations. In other words, the exclusive use of the seabed's mineral resources based on the geographically privileged position of a nation was not considered to be detrimental to the interests of other nations.

Thus, in 1958, the Continental Shelf Convention, ${ }^{5}$ concerned with the distribution of seabed petroleum resources only among the respective beneficial coastal nations, was adopted without difficulty. At that time there was no possibility of exploiting the mineral resources of the seabed beyond the continental shelf, which was widely understood as not extending beyond the two hundred metre isobath. The problem was not one of law, but rather one of geography or geology, which would not necessarily cause any conflict of national interests. If there were any conflicts, these would result mainly from the determination of the boundary of the continental shelf that each nation could claim.

This calm situation was broken, however, in the mid-1960's after only two decades, when the United States oil industry began to find it technologically possible to extract resources even from under one or two thousand metres of water, on the continental slope. The exclusive claims of coastal nations to the continental slope far beyond the general two hundred-metre depth-line limit of the continental shelf would still have been permissible in terms of the exploitability criterion in the Continental Shelf Convention. Yet there was another interest in the United States, represented by the hard minerals industry, which had begun to set its sights on the exploitation of manganese nodules at the bottom of the vast ocean. It would be contrary to their interest to see an extension of the exclusive areas reserved for the coastal nations, thus diminishing the areas that would otherwise have been open to them.

In 1967, noting these conflicting interests between the oil industry and the hard minerals industry, the Maltese delegate to the United

4. Policy of the United States with Respect to the Natural Resources of the Subsoil and Sea-Bed of the Continental Shelf, Proclamation No. 2667, 3 C.F.R. 67 (1943-1948 Compilation), reprinted in $1 \mathrm{~S}$. Oda, The IntBrnational Law op the Ocean DevelopMENT 341 (1976).

5. Convention on the Continental Shelf, Apr. 29, 1958, U.S.T. 471, T.I.A.S. No. 5578, 499 U.N.T.S. 311. 
Nations took a step towards halting the gradual extension of coastal jurisdiction for mineral resources, thus reserving the vast deep-ocean floor for the benefit of the world in terms of the common heritage of mankind. As was only natural, the concept of the common heritage of mankind received wide support from a group of developing countries which could dream of some benefits accruing to them from such a concept through the avoidance of competition with the powerful developed nations in the exploitation of the seabed, which was still far beyond their own technical capability.

The conflict between the claim to a wider area for the exclusive use of mineral resources for each coastal nation, and the demand to retain as much of the vast ocean areas as possible for the benefit of the whole world, seems to have only just been resolved by a compromise agreement reached after the past ten years of debate in the United Nations Seabed Committee and UNCLOS III. The Draft Convention on the Law of the Sea which was prepared just one year ago provides for the redefinition of the continental shelf. ${ }^{6}$ In contrast to the 1958 Convention, and also from the geographical concept, the definition now suggested, containing more than five hundred words, is not easy to grasp at first glance. ${ }^{7}$ At any rate, however, it is safe to say that practically all exploitation of offshore petroleum extending to the outer edge of the continental margin will fall under the exclusive control of each coastal nation.

Now let me turn to the exclusive economic zone. The history of ocean fishing is more complicated than the case of the exploitation of seabed mineral resources. The difference lies in the fact that the principle of free access was believed to have existed more strongly in ocean fishing. A claim to the extension of the coastal nations' fishery jurisdiction, which would be a blow to the then-established laissez-faire policy in ocean fishing, would invite the opposition of those nations which would otherwise have enjoyed the freedom of fishing in such claimed

6. Draft Convention (Informal Text), supra note 2, art. 76.

7. Id. Article 76 is composed of ten sections and corresponds to article 76 in the Draft Convention, supra note 2 , and states in relevant part:

1. The continental shelf of a coastal State comprises the sea-bed and subsoil of the submarine areas that extend beyond its territorial sea throughout the natural prolongation of its land territory to the outer edge of the continental margin, or to a distance of 200 nautical miles from the baselines from which the breadth of the territorial sea is measured where the outer edge of the continental margin does not extend up to that distance.

3. The continental margin comprises the submerged prolongation of the land mass of the coastal State, and consists of the sea-bed and subsoil of the shelf, the slope and the rise. It does not include the deep ocean floor with its oceanic ridges or the subsoil thereof. 
offshore areas, since the limit of the territorial seas had been regarded as coincident with the exclusive fishing interest of the coastal States.

In this field also, the role played by the United States in the postwar period was not insignificant, and in the United States itself there were two opposing fishery interests, one represented by the coastal fishing industry, particularly on the North Pacific coast, and the other by the highly migratory tuna industry. In the post-war period, the United States fishing industry on the North Pacific coast began to realize that the three-mile territorial sea guaranteeing its exclusive interest would probably not be sufficient to secure its profits in offshore fishing, owing to the increasing competitive potential of the Japanese fishing industry. Such a specific interest off the Pacific coast would have been satisfied through bilateral negotiations with Japan, which could have agreed to abstain from such fishing. Instead, the 1945 Proclamation of the United States President concerning offshore fisheries ${ }^{8}$ took a step towards expansion of fishery jurisdiction. Then it was not difficult for any developing country, particularly in Latin America, to understand that it would benefit simply by extending its area of coastal jurisdiction, thus monopolizing the fishery income deriving therefrom or profiting by the revenues of taxation imposed on foreign fishing there. Such an expansion policy could not, however, constitute an overall national policy for the United States which, as an advanced fishing nation, did not want to see the ocean diminished to the detriment of its interest in free fishing.

At the First and Second Conferences on the Law of the Sea in 1958 and 1960 , respectively, the problem of the limit of the territorial sea was discussed in connection with the problem of the fishery zone. Against the movement towards expansion of fishery jurisdiction, the United States expressed its readiness to recognize the wider claim to fishery jurisdiction only on condition that the limit of the territorial sea be maintained as narrow as possible. The reason for this was quite clear and, as I said at the outset, it was categorically imperative for the United States to maintain the unhindered passage of warships through narrow international straits, even at the sacrifice of any other interests, particularly in fishing. In fact, the nations that wanted to keep the jurisdiction of each coastal State as narrow as possible from the fishery resource aspect, so as to keep open as wide an area as possible for free fishing, were only a handful of the nearly one hundred participating countries in the conferences of 1958 and 1960. The views of the nations favouring wider fishery jurisdiction were powerful, because the principle of laissez-faire, or free access, which would apply to fishing beyond

8. Policy of the United States with Respect to Coastal Fisheries in Certain Areas of the High Seas, Proclamation No. 2668, 3 C.F.R. 68 (1943-1948 Compilation), reprinted in $1 \mathrm{~S}$. Oda, The International Law of the Ocean Development 342 (1976). 
coastal jurisdiction, could benefit only those who were strong enough to rely upon this principle. Even though, in the conferences of 1958 and 1960 , extension of coastal fishery jurisdiction as such was not accepted, no one could doubt that the trend the world was following at that time could be deviated from no longer.

Being aware of this trend, the United States knew in the late 1960 's and early 1970's that it could not but give support to the claims to wider fishery jurisdiction in order to secure the unhindered passage of warships through international straits. At the United Nations Seabed Committee, the concept of the exclusive fishery zone and that of the patrimonial sea were introduced respectively by Kenya in $1972^{\circ}$ and by Mexico and a few other Caribbean countries in 1973. ${ }^{10}$ No one could divert this trend of expansion of the exclusive interest of the coastal States aimed at enjoyment of the fishing resources in offshore areas. The only possibility was to attempt to mitigate the exclusiveness claimed by the coastal States by imposing some restrictions on their competence.

Thus, Part V of the Draft Convention of the Law of the Sea (Informal Text) of 22 September 1980 comprising twenty-one articles, provides for a new regime of the exclusive economic zone. ${ }^{11}$ Certainly the exclusive economic zone as defined in the Draft Convention is different from a simple expansion of the territorial sea, in that some restrictions are imposed on the competence of the coastal States. There are still many ambiguities left in this concept, but no one today doubts that fishing in the exclusive economic zone falls within the exclusive interest of the coastal States. Whatever the outcome of UNCLOS III in the years to come, there does not remain any doubt that the concept of the exclusive economic zone has its firm position in customary international law.

What I have been talking about concerning the continental shelf and the exclusive economic zone may be summarized as follows: in the offshore areas now, which, just like the land areas, cover approximately one-third of the globe, exclusive control of resoures has been established through UNCLOS III in favour of the geographically-privileged nations, in terms of the redefined continental shelf for mineral resources and the exclusive economic zone for fishery resources. Such development in the past three-and-a-half decades has completely

9. U.N. Doc. A/AC.138/SC.II/L.10 (1972).

10. U.N. Doc. A/AC.138/SC.II/L.21 (1973) (submitted by Colombia, Mexico and Venezuela).

11. Draft Convention (Informal Text), supra note 2, arts. 55-75. These articles correspond to articles 55-75 in the Draft Convention, supra note 2, with some modifications in relation to delimitation of the exclusive economic zone between States with opposite and adjacent coasts. 
changed the meaning of the ocean as interpreted under traditional international law. And I have no doubt that the concept of permanent sovereignty over natural resources, which has already been established for land resources, will eventually apply to those marine resources which fall under the exclusive control of each coastal State.

There still remains another half of the ocean, covering one-third of the globe, that is not placed within the exclusive control of each coastal nation. The problem that faces us now and in the future relates to how the marine resources in this remaining half of the ocean should be treated under international law. These resources are mineral resources beyond the outer limit of the continental shelf, and fishery resources beyond the exclusive economic zone.

With regard to the mineral resources in the seabed of the vast ocean beyond the limit of the continental shelf, the concept of the common heritage of mankind is now being suggested. Taking an initiative in this direction, for the first time at the United Nations General Assembly, the delegate of Malta, in 1967, considered that the time had come to declare this area to be the common heritage of mankind and proposed that immediate steps should be taken to draft a treaty for such a purpose. ${ }^{12}$ After three years of deliberations at the United $\mathrm{Na}$ tions Seabed Committee, the United Nations General Assembly declared in 1970 that this area and the resources of the area were the common heritage of mankind, and that all activities regarding the exploitation of these resources should be governed by an international regime to be established in the future. ${ }^{13}$

The deliberations and negotiations continued for ten years, and UNCLOS III has now produced a set of very detailed provisions on this question in the Draft Convention on the Law of the Sea (Informal Text), prepared last year. Fifty-nine articles in Part XI concerning this area, twenty-two articles in Annex III on Basic Conditions of Prospecting, Exploration and Exploitation and thirteen articles in Annex IV on Statute of the Enterprise, are devoted to the exploitation of this area and its mineral resources, which are defined as the common heritage of mankind.

Yet for the past few years, UNCLOS III has run onto the rocks. The main problems still remaining to be solved at future sessions are the composition of the Council of International Seabed Authority, which is to have decisive competence in the exploitation of this area,

12. 22 U.N. GAOR, U.N. Doc. A/6695 (1967). See also 22 U.N. GAOR C.1 (1515 mtg.), U.N. Doc. A/C.1/P.V.1515 (1967).

13. G.A. Res. 2749, 25 U.N. GAOR, U.N. Doc. A/C.1/544 (1970). 
and the participation of private enterprises in parallel with direct exploitation by international enterprises. It is reported that the United States blocked UNCLOS III early this year, mainly because the Reagan Administration was not yet in a position to determine its own policy towards this particular problem. This reflects the dissatisfaction felt by the hard-mineral industries of the United States, with the ways and means of exploitation suggested in the Draft Convention.

Now I will turn to ocean fishing. Here the concept of the common heritage of mankind has not been suggested in any formal forum of the United Nations, because it has traditionally been considered that the freedom of fishing has existed. But I submit that the real and difficult problems of fishing have not been touched upon in past discussions at UNCLOS III and are now left for future discussions.

Suggestions were often made at the early stages of UNCLOS III to drop fishing from the list of the freedoms of the high seas. The Draft Convention on the Law of the Sea (Informal Text) does mention as one of the six freedoms of the high seas that of fishing, but subject to certain conditions concerning management and conservation of the living resources of the high seas. ${ }^{14}$ It suggests the cooperation of States in the management and conservation of living resources, but without mentioning any concrete substance of management. ${ }^{16}$ I submit that the drafting of the provisions concerning high seas fisheries is very imprecise: the duty for cooperation seems rather abstract and there is no provision referring to how international cooperation in the management and conservation of high seas fishery resources can be carried out in a concrete way. Considering this problem of the management and conservation of high seas fisheries, it will perhaps be as well to reflect for a moment on the history of high seas during the past decades.

In the post-war period, the necessity of joint conservation measures had come to be widely recognized for certain species of living resources, and this has never been contested by any nation. The principle of free competition among States, however, obtains only where demands upon resources do not overwhelmingly exceed the amount of allowable catch, and conservation measures take the form of restrictions on permissible fishing gear, fishing seasons, or fishing areas. If a fundamental change in circumstances should occur, each State will undoubtedly be inclined to minimize its own sacrifice and to maximize its

14. Draft Convention (Informal Text), supra note 2, art. 16, which now corresponds to article 116 in the Draft Convention, supra note 2, provides: "All States have the right for their nationals to engage in fishing on the high seas subject to: (a) Their treaty obligation; (b) The rights and duties as well as the interests of coastal States . . .."

15. Draft Convention (Informal Text), supra note 2, art. 117, which corresponds to article 117 in the Draft Convention, supra note 2, provides: "All States have the duty to take, or to cooperate with other States in taking, such measures for their respective nationals as may be necessary for the conservation of the living resources of the high seas." 
own share of resources quite independently of any reasoning in favour of preferential distribution of resources.

This problem may best be illustrated by a simple example. If the total possible catch of a certain species is one hundred and fifty, and prudent conservation practice demands that the total allowable catch be only one hundred, the burden of abstaining from harvesting the additional fifty will have to be imposed in some way upon the States concerned in exploiting the available one hundred. Each State may, of course, freely compete in fishing within the total allowable catch of one hundred. Free competition, however, does not satisfy States which so substantially preempt the fisheries concerned that fishing by any newcomer will necessarily decrease their own catch, nor will it be acceptable to nations with less advanced technologies and economies.

In such cases, conflict will inevitably occur between two parties who might otherwise agree upon the desirability of conservation of marine living resources. One will adhere to traditional arguments of free competition in fishing on the high seas, especially since its own technology and economy can bring it a larger share of resources, while the other, seeking to assure itself of a constant, preferably large, share of the resources, might invoke all kinds of reasoning in an attempt to keep its competitors from exploiting the areas it considers most important. The problems inherent in the allocation of limitations have in fact made it difficult to reconcile conflicting national interests even among those States that are most vitally concerned with the conservation of resources.

The case of Antarctic whaling may offer an interesting example of the allocation of marine living resources among the various States. Antarctic whaling had been open to those countries which, under the 1946 Whaling Convention, were able to compete freely for their maximum share within the total limit set by the International Whaling Commission. ${ }^{18}$ Several countries, all of which were advanced nations, were engaged in Antarctic whaling in expeditions known as the "whaling olympic." These activities had been generally regarded as typical of exploitation respecting conservation requirements on an international level. Towards the end of the 1960's, however, it had become increasingly difficult to maintain a system of free competition. The allocation of quotas among the States concerned, based simply on the result of negotiations each year, has become the practice in Antarctic whaling, replacing the "whaling olympic."

The decline of the laissez-faire policy which had been maintained in ocean fishing, even potentially, during past centuries, coincides with the growing concept of the common heritage of mankind suggested for

16. For a discussion of the regulations regarding Antarctic whaling, see $S$. ODA, INternational Law of the Resources of the Sea 51 (1979). 
the mineral resources of the deep ocean floor. Certainly in the case of ocean fishing, the problems are different from those encountered in seabed development, as some nations may claim that they already possess certain fishing rights in the vast ocean, acquired on the basis of longstanding fishing operations. Yet these advanced nations are very limited in number. I think that discussions will eventually be held on the new concept of the common heritage of mankind applicable to ocean fishing similar to those discussions centered on seabed mineral resources in UNCLOS III.

\section{VI}

I cannot conclude my talk without referring very briefly to a further difficult problem relating to the future Law of the Sea, which represents another aspect of the development of ocean resources. That is the issue of protection of the marine environment. With regard to marine pollution, the Law of the Sea, like environmental issues in general, is facing the basic problem of "development versus protection of the environment." One of my friends said at UNCLOS III: "Poor pollution, no one is in your favour." There are always pros and cons to the various topics at UNCLOS III, but certainly no one has ever been in favour of marine pollution. If disposal of waste or discharge of pollutants into the sea were to be completely prohibited, the problem would then be much simpler - at least, for those unconcerned with land pollution. The disposal of some waste, and the discharge of some pollutants as a result of economic development are, however, unavoidable. In fact, the sea becomes ever more attractive to any nation or to any industry for this purpose. If we were to completely prohibit this activity, we would have to run down a great deal of industrial and social progress, and the cost would be extremely high. The shipping industry too, would labour under an immense and costly handicap.

Thus, although no one ever doubts the necessity of environmental protection of the ocean, stringent environmental control could raise opposition from industry. A balance must be struck between the two opposite policies, namely the encouragement of economic development and the protection of the marine environment. In addition, a further consideration is how to spread the burden between the different nations: the burden of sacrificing economic development for the protection of the marine environment. We find ourselves confronted by maximum levels of pollution, and the concomitant necessity that we consider how to parcel out restrictions on industry to prevent further pollution. Aside from the question of whether the parcelling should be done by industry or by nation, it is noteworthy that among the developing nations there are those for whom "development" takes precedence over "environment." While saddling the developed countries 
with the burden of preventing marine pollution, they expect to continue developing as they see fit, free from all restrictions. Some years ago I predicted that the concept of the common heritage of mankind would also be introduced in this respect, and said that this might become one of the topics to be discussed at any future conference on the Law of the Sea. Here again the Law of the Sea may eventually face problems related to how to allocate sacrifices imposed in environmental protection as each nation, in its relationship with other countries, tries to minimize the burden on its industry necessitated by pollution control, even while recognizing the existence of overall limits.

\section{VII}

I now come to the conclusion, or rather, I now come to the point where I must pose questions. On the one hand, the question of exclusive use being reserved to each coastal nation has now become defined in terms of either the concept of the redefined continental shelf or that of the exclusive economic zone. On the other hand, in the areas beyond, the concept of the common heritage of mankind has been introduced for the exploitation of their mineral resources, and in the future, almost without doubt, this concept will also apply to fishery resources or even to protection of the marine environment. What really faces us today is, first, how to distribute and allocate the limited amount of ocean resources, mineral or living, among the sovereign nations, each of which will, naturally, try to maximize its own share. Second, how to distribute and allocate among the sovereign nations the sacrifices - and again each nation will, naturally, try to minimize its own sacrifice involved in protection of the marine environment necessitated by economic development.

Does simply suggesting the concept of the common heritage of mankind provide us with any solution? What does the phrase "common heritage of mankind" really mean? What is the substance behind this expression? I am not in a position to comment on what the legal implications the 1970 United Nations General Assembly resolution might have. The declaration does not necessarily specify by whom and how the deep ocean floor could be developed, nor by whom and how the benefits would be shared. The substance of the "common heritage of mankind" involves various interpretations. The idea of liberty as distinct from license has always implied certain checks and balances. If, however, this idea of freedom is to be denied and replaced by some new idea of justice, then new principles must be worked out. The mere words "common heritage of mankind" are pious, but empty. To simply formulate some machinery is also useless. As the issues discussed at UNCLOS III are related to the areas which are considered those of the common heritage of mankind, the interests of land-resource-possessing 
and non-possessing countries are so conflicting as to raise the spectre of bloody confrontations.

What kind of idea in principle can we obtain if we are to put substance into the conceptual expression "common heritage of mankind"? If we consider the complexities of national interests that are still strongly projected onto the common heritage, then it can be said that international society has not yet developed to such a high level of responsibility or harmony that we can talk with common understanding of the "common heritage of mankind." People today appear to be satisfied with the mere, somewhat beautiful-sounding, words. As I stated at the outset, land resources are unevenly divided among the sovereign nations, developed or developing, and offshore resources are reserved only for the benefit of the geographically-privileged coastal nations. Considering this, the problem of how to implement the concept of the common heritage of mankind with regard to sharing the benefits of the vast ocean resources, and sharing the sacrifices or burdens of economic development for the protection of the vast ocean, must be seen as a dominant problem which it is urgent to face and solve.

I have not given any solution, nor even a hint of any solution, to these difficult problems of resource-sharing and burden-sharing. I intend only to suggest that we should go beyond a simple playing with the beautiful catchphrase, "common heritage of mankind." To do so will require close examination by not only international lawyers, but also economists, political scientists, and even philosophers, who are concerned with the future fate of the world community. That examination will be necessary, moreover, not for the sole sake of the Law of the Sea, but in order to put real backbone into the New International Economic Order, a concept that is now gaining ground in every corner of the world, and which likewise must not be allowed to remain a mere shibboleth.

Mr. Dean, distinguished members of the Facuity, ladies and gentlemen, allow me once more to thank you sincerely for the honour you have done me and for lending me your kind attention. 